\title{
Susceptibility of Triatoma sordida Stal, 1859 (Hemiptera: Reduviidae) to alpha-cypermethrin under natural climatic conditions
}

\author{
Grasielle Caldas DÁvila Pessoa ${ }^{[1]}$, Aline Cristine Luiz Rosa ${ }^{[1]}$, Letícia Cavalari[1], \\ João Geraldo de Rezende ${ }^{[2]}$, Bernardino Vaz de Mello ${ }^{[3]}$ and Liléia Diotaiuti ${ }^{[1]}$
}

[1]. Laboratório de Referência em Triatomíneos e Epidemiologia da Doença de Chagas, Centro de Pesquisas René Rachou, Fundação Oswaldo Cruz, Belo Horizonte, Minas Gerais, Brazil. [2]. Gerência Regional de Saúde de Montes Claros, Montes Claros, Minas Gerais, Brazil. [3]. Secretaria de Saúde do Estado de Minas Gerais, Governo do Estado de Minas Gerais, Belo Horizonte, Minas Gerais, Brazil.

\begin{abstract}
Introduction: Despite the recommendations by interpretation of resistance ratios obtained in laboratory bioassays, little is known about the actual impact of these results in the effectiveness of vector control activities in the field. In this context, our objective was to determine the mean value of different resistance ratios obtained by laboratory bioassays performed as part of the chemical control strategies of Triatoma sordida in the field. Methods: Field bioassays were developed in Monte Azul and Coração de Jesus (Southeast, Brazil). In each location, samples were formed with three domestic units treated with alpha-cypermethrin $20.0 \%$ (Alfatek ${ }^{\circledR} 200$ SC). One day after spraying, 10 fifth-instar nymphs remained in contact with the surfaces treated (adobe with plaster, adobe without plaster, or wood) with insecticide in plastic cones for $72 \mathrm{~h}$. Three cones were exposed inside the intradomicile and the peridomicile. The insects in the control group were exposed to an insecticide-free piece of cardboard. Mortality was measured $72 \mathrm{~h}$ after removal of the insects from the treated surfaces. The tests were realized in triplicate. Results: Mortality was $100.0 \%$ in all locations, except for Monte Azul; Landinho (96.6\%) and Coração de Jesus; Barriguda (96.6\%). Conclusions: Although the resistant populations in laboratory tests proved to be susceptible in the field, this observation is not sufficient to suggest that the cut-off points used to justify the resistance ratio should be changed. In this sense, we recommend that laboratory and field bioassays are carried out with a greater number of Triatominae populations to allow more in-depth consideration of the subject.
\end{abstract}

Keywords: Triatoma sordida. Field bioassays. Alpha-cypermethrin susceptibility.

\section{INTRODUCTION}

Insecticide resistance results in a decrease in the mortality observed in a population subjected to continuous treatment. This characteristic is expressed by a greater number of specimens that tolerate lethal doses compared with specimens considered sensitive during the initial application of the product, leading to selection pressure in populations. This phenomenon is based on the genetic variability of natural populations. Consequently, this variabilility combined with insecticide pressure results in selection of certain phenotypes and the subsequent increase in resistance gene frequencies ${ }^{(1)}$.

Corresponding author: Dra. Liléia Diotaiuti. Laboratório de Referência em Triatomíneos e Epidemiologia da Doença de Chagas/CPqRR/FIOCRUZ. Av. Augusto de Lima 1715, Barro Preto, 29190-002 Belo Horizonte, Minas Gerais, Brasil.

Phone: 5531 3349-7763; Fax: 5531 3295-3115

e-mail: diotaiuti@cpqrr.fiocruz.br

Received 19 March 2015

Accepted 9 July 2015
Until recently, insecticide resistance in triatomines was considered to be $a d h o c$ and not very likely to occur, considering their long life cycle (i.e., even if there are resistant individuals, the selection process is expected to be very slow) and a low genetic variability in the population, which implies only very rare individuals will be genetically predisposed to insecticide sensitivity ${ }^{(2)}$. Since then, however, studies of the response of different species to several insecticides, suggest that such a phenomenon is distributed in an area larger than the one currently known, and therefore requires more characterization and delimitation. Most published studies refer to Triatoma infestans populations with high resistance ratios $50 \%\left(\mathrm{RR}_{50}>50\right)$, from Bolivia and Argentina, in areas where vector control is difficult. Research on the susceptibility of triatomines in Venezuela, Colombia, and Paraguay are still quite $a d h o c$, and address such problems with vector control of Rhodnius prolixus, Triatoma infestans, Triatoma maculata, Triatoma dimidiata, and Panstrongylus herreri. As for Brazilian triatomines, investigative studies on the susceptibility to insecticide are on the rise and have focused on Triatoma brasiliensis, Triatoma sordida, Panstrongylus megistus, and T. infestans collected in areas with reports of persistent triatominic infestations $\left(\mathrm{RR}_{50}<8\right)^{(3)}$. 
There are two recomendation to justify the resistance ratios ${ }^{(4)}{ }^{(5)}$. According to Zerba \& Picollo ${ }^{(4)}$, populations with an $\mathrm{RR}_{50}>2$ are considered resistant, while according to the Pan-American Health Organization (PAHO) $)^{(5)}$, populations with an $\mathrm{RR}_{50} \geq 5$ are considered resistant. The following recommendations have been proposed for these resistant populations: 1) investigate possible operational failures in the vector control strategies performed by the National Program of Chagas Disease Control (NPCDC); 2) replacement of the insecticide used by the NPCDC with another that has a distinct mode of action, and 3) further susceptibility monitoring studies on the timeline.

However, despite the recommendations by Zerba \& Picollo(4) and $\mathrm{PAHO}^{(5)}$, little is known about the resistance ratios observed in laboratory bioassays on the efficacy of vector control activities in the field. This implies that bioassays should be conducted both at the laboratory and in the field, in a simultaneous and complementary manner, to allow for assessments of point-to-point situations and, consequently, recommendations of rational and timely procedures for triatomine control strategies. In this context, the objective of this study was to determine the mean value of different resistance ratios obtained by laboratory bioassays in the chemical control strategies in the field. We selected populations of T. sordida that had the deltamethrin susceptibility profiles described by Pessoa et al. ${ }^{(6)(7)}$, presenting different $\mathrm{RR}_{50}(1.30-7.01)$, (Table 1).

\section{METHODS}

\section{Insect sampling}

The triatomines were manually collected in November 2013, without using a dislodging agent from peridomiciles, in endemic areas of Minas Gerais where the National Program of Chagas Disease Control had performed continuous and systematic applications of insecticides with residual action over the last 30 years: Monte Azul ( $\left.15^{\circ} 09^{\prime} 18^{\prime \prime} \mathrm{S} 42^{\circ} 52^{\prime} 30^{\prime \prime} \mathrm{O}\right)$ and Coração de Jesus ( $\left(16^{\circ} 41^{\prime} 06^{\prime \prime} \mathrm{S} 44^{\circ} 21^{\prime} 54^{\prime \prime} \mathrm{O}\right)$. This region has a semiarid climate with high temperatures $\left(18-32^{\circ} \mathrm{C}\right)$, dry $(54-58 \%$ $\mathrm{RH}$ - relative humidity) and irregular rainfall concentrated in a few months of the year ${ }^{(3)}$.
All insects collected were identified using the taxonomic key of Lent and Wygodzinsky ${ }^{(8)}$ and maintained under controlled conditions of temperature and humidity $\left(25^{\circ} \mathrm{C} \pm 1{ }^{\circ} \mathrm{C}\right.$; $60 \% \pm 10 \% \mathrm{RH}$ ) in insectary of Laboratório de Referência em Triatomineos e Epidemiologia da Doença de Chagas of the Fundação Oswaldo Cruz (FIOCRUZ). They were fed weekly with mouse blood (Swiss Webster) for growth of the colonies so as to allow the tests in the field.

\section{Chemicals}

Alfatek ${ }^{\circledR} 200$ SC (alpha-cypermethrin, 20.0\%) used for the bioassays was obtained from Rogama Indústria e Comércio Ltda, Brazil. This insecticide is currently used by the Ministry of Health of Brazil for the National Program of Chagas Disease Control in the Brazil.

\section{Field bioassays}

The field bioassays were carried out in the locations of origin of the triatomines in September, 2014. In Monte Azul and Coração de Jesus, a sample was formed with three domestic units (DUs) as shown in Table 2, comparable in terms of type of surface (adobe with plaster) and environmental characteristics, treated with alpha-cypermethrin at a concentration of $25 \mathrm{mg}$ a.i. $/ \mathrm{m}^{2}$. Spraying was carried out by agents of endemic diseases in the region, as recommended by the Ministry of Health ${ }^{(9)}$. A Guarani hand sprayer was used attached to a Tee-jet 8002 nozzle. Tests were conducted simultaneously, using the same methodology, on adobe surfaces without plaster or wood, in order to evaluate the influence of the substrate type on the availability of the sprayed insecticide in locations where populations with the highest $\mathrm{RR}_{50}$ were reported by Pessoa et al. ${ }^{(6)(7)}$. One day after spraying the DUs, 10 fifth-instar nymphs (second generation), 14 days after the imaginal moult and 7 days after feeding, were submitted to wall surface tests according to recommendations by the World Health Organization $(\mathrm{WHO})^{(10)}$. The insects remained in contact with the surfaces treated with alpha-cypermethrin in plastic cones with 9-cm diameter (developed by WHO for susceptibility studies with mosquitoes) for $72 \mathrm{~h}$. Then, the triatomines were removed and transferred to insecticide-free bottles and kept in an insectary. Three cones were exposed inside the intradomicile and three cones around the peridomicile of each treated DU.

TABLE 1 - Deltamethrin toxicological profile in peridomestic Triatoma sordida from North of Minas Gerais, Brazil.

\begin{tabular}{|c|c|c|c|}
\hline Municipality/location & $\mathbf{R R}_{\mathbf{5 0}}$ & \multicolumn{2}{|c|}{ Deltamethrin toxicological profile } \\
\hline Monte Azul; Porteiras & $1.30 *$ & Susceptible & Susceptible \\
\hline Monte Azul; Landinho & $1.63^{*}$ & Susceptible & Susceptible \\
\hline Monte Azul; Canabrava & $2.63 *$ & Resistant & Susceptible \\
\hline Coração de Jesus; Barriguda & $7.08 * *$ & Resistant & Resistant \\
\hline
\end{tabular}

$\mathbf{R R}_{50}$ : resistance ratio 50\%; PAHO: Pan American Health Organization. *Data from Pessoa et al. ${ }^{(6)}$. ${ }^{* *}$ Data from Pessoa et al. ${ }^{(7)}$. 
TABLE 2 - Mortality of fifth-instar nymphs of Triatoma sordida with different deltamethrin toxicological profiles in response to exposure on surfaces impregnated with alpha-cypermethrin $20.0 \%$, $72 \mathrm{~h}$ after contact with the treated surfaces; $(p=0.00062$, experimental versus control group, Mann-Whitney test).

\begin{tabular}{|c|c|c|c|c|c|c|c|c|c|c|c|c|c|}
\hline \multirow{3}{*}{\multicolumn{2}{|c|}{$\begin{array}{l}\text { Population: municipality/location } \\
\left(\mathrm{RR}_{50}\right)\end{array}$}} & \multicolumn{6}{|c|}{ Intradomicile } & \multicolumn{6}{|c|}{ Peridomicile } \\
\hline & & \multicolumn{3}{|c|}{ Experimental group } & \multicolumn{3}{|c|}{ Control group } & \multicolumn{3}{|c|}{ Experimental group } & \multicolumn{3}{|c|}{ Control group } \\
\hline & & \multirow{2}{*}{$\begin{array}{c}\text { tested } \\
\mathrm{n}\end{array}$} & \multicolumn{2}{|c|}{ dead } & \multirow{2}{*}{$\begin{array}{l}\text { tested } \\
\mathrm{n}\end{array}$} & \multicolumn{2}{|c|}{ dead } & \multirow{2}{*}{$\begin{array}{c}\text { tested } \\
n\end{array}$} & \multicolumn{2}{|c|}{ dead } & \multirow{2}{*}{$\begin{array}{c}\text { Tested } \\
\text { n }\end{array}$} & \multicolumn{2}{|c|}{ dead } \\
\hline & Type of surface & & $\mathbf{n}$ & $\%$ & & $\mathbf{n}$ & $\%$ & & $\mathbf{n}$ & $\%$ & & $\mathbf{n}$ & $\%$ \\
\hline $\begin{array}{l}\text { Monte Azul; Porteiras } \\
\left(\mathrm{RR}_{50} 1.30\right) *\end{array}$ & Adobe with plaster & 90 & 90 & 100.0 & 90 & 0 & 0.0 & 90 & 90 & 100.0 & 90 & 0 & 0.0 \\
\hline $\begin{array}{l}\text { Monte Azul; Landinho } \\
\left(\mathrm{RR}_{50} 2.72\right) *\end{array}$ & Adobe with plaster & 90 & 90 & 100.0 & 90 & 0 & 0.0 & 90 & 89 & 96.6 & 90 & 0 & 0.0 \\
\hline Monte Azul; Brejinho & Adobe with plaster & 90 & 90 & 100.0 & 90 & 0 & 0.0 & 90 & 90 & 100.0 & 90 & 0 & 0.0 \\
\hline
\end{tabular}

$\mathbf{R R}_{50:}$ resistance ratio $50 \%$. ${ }^{*}$ Data from Pessoa et al. ${ }^{(6)} . * *$ Data from Pessoa et al. ${ }^{(7)}$.

The insects of the control group were exposed to an insecticidefree piece of cardboard attached to the wall in the same environments of the intradomicile and peridomicile of each DU, where the experimental groups were exposed. Mortality was measured $72 \mathrm{~h}$ after removal of the insects from the treated surfaces. Triatomines were considered dead when they were placed on a filter paper and did not show locomotor activity, either spontaneously or when stimulated with forceps. Signs of paralysis and lack of coordination of the nymphs to move was considered as well.

\section{Statistical analysis}

Results from the experiments were analyzed through nonparametric hypothesis tests. Considering the nature of the data to be compared (2 independent samples), we used the MannWhitney test, and differences between groups were considered significant when $p$-values were below or equal to $\alpha=0.05$.

\section{Ethical considerations}

This study was approved by the Animal Ethics Committee of Fundação Oswaldo Cruz (number 29/14-1).

\section{RESULTS}

The mortality rate, assessed $72 \mathrm{~h}$ after the removal of the insects from the areas with insecticide, was $100 \%$ in all locations, except for Landinho (96.6\%) and Barriguda (96.6\%). Tests conducted in Brejinho and Barriguda, on adobe surfaces without plaster or on wood, both showed $100 \%$ mortality (Table 2). Thus, by using the criterion recommended by $\mathrm{WHO}^{(10)}$, all populations were considered susceptible to alpha-cypermethrin.
For every population and surface considered, in peridomicile and intradomicile, the Mann-Whitney test performed comparing the exposed and the control groups generated a $\mathrm{p}$-value = $0.00061(\mathrm{p}<0.05)$. Thus, mortality rates were significantly different between the 2 groups compared.

\section{DIscussion}

Despite the growing number of studies that characterize the toxicological profile of different triatomine populations to insecticides, there is only one study in the literature that has evaluated the actual impact of resistance ratios found in laboratory bioassays on triatomine control strategies in the field. In a laboratory test, Obara ${ }^{(11)}$ characterized the susceptibility of three Brazilian populations of T. brasiliensis from Oieiras (Piauí) to deltamethrin $\left(\mathrm{RR}_{50} 1.75-2.17\right)$ in the laboratory bioassays. Then exposed first-instar nymphs to different substrates (clay, adobe without plaster, and unpainted wood) impregnated with deltamethrin WG250 (a commercial product) at a concentration of $25 \mathrm{mg}$ a.i. $/ \mathrm{m}^{2}$. Regardless of the $\mathrm{RR}_{50}$ of each population, each was susceptible to the insecticide, as evidenced by a $100 \%$ mortality rate. However, these results should be interpreted with caution, as fifth-instar nymphs are known to be more resistant than first-instar nymphs ${ }^{(12)}$.

In this study, we evaluated the susceptibility of five populations of $T$. sordida collected in areas with persistent infestations and presenting different deltamethrin susceptibility profiles. According to Zerba \& Picollo ${ }^{(4)}$, three populations (Monte Azul; Porteiras and Monte Azul; Landinho) are resistant to deltamethrin $\left(\mathrm{RR}_{50}>2\right)$. In contrast, according to $\mathrm{PAHO}^{(5)}$ only the population of Barriguda (Coração de Jesus) is resistant. 
Regardless of the criteria adopted by Pessoa et al. ${ }^{(6)(7)}$, our field bioassays showed that all study populations were susceptible to alpha-cypermethrin. The lack of correlation between the results of the laboratory and field bioassays may be due to the use of different pyrethroids in these assays. Although both deltamethrin and alpha-cypermethrin are pyrethroids, and they therefore have the same site of action in the nervous system of triatomines (sodium channels), many studies (laboratory bioassays) with several triatomine species have demonstrated different toxicological profiles in response to different pyrethroids ${ }^{(13)}$. The lack of correlation between the laboratory and field bioassays may be due to the use of nymphs in different stages of development. In laboratory bioassays, first-instar nymphs are used since it is difficult to obtain the high sample numbers needed to complete testing (e.g. 400 specimens). On the other hand, the field bioassays are conducted with fifthinstar nymphs considering that these are more resistant to insecticides ${ }^{(12)}$. Because of these methodological differences, the World Health Organization ${ }^{(10)}$ recommends that laboratory bioassays are used as an initial test to indicate possibly resistant populations, being subjected to field bioassays to confirm or not the insecticide resistance.

Degradation of the insecticide in the peridomicile is faster than that in the intradomicile, because of exposure to sunlight (ultraviolet radiation) and other weather conditions (e.g., rain and ultraviolet radiation). This effect is clear in the timeline ${ }^{(14)(15)(16)}$. As the field bioassays were carried out one day after spraying, we believe there is no difference in insecticide availability between the intradomicile and the peridomicile. Our hypothesis was confirmed in all study DUs, where we observed $100 \%$ mortality in both environments, with the exception of one DU in Landino (96.6\%) and one in Barriguda (96.6\%). We believe that the survival of these two triatomines may be related to lower individual susceptibility ${ }^{(5)}$.

The adobe surface with plaster was chosen because this surface is most commonly found in DUs in the region. However, we note that there is a distinct $\mathrm{pH}$ difference between the surfaces, depending on the material used in their manufacture; this could affect the rate of pesticide degradation ${ }^{(15)(16)}$. This variable was excluded from our assays because exposure to treated surfaces was performed $24 \mathrm{~h}$ after spraying. Furthermore, we note that the porosity of sprayed surfaces is directly related to pesticide absorption and its consequent availability in the environment. For this reason, the insecticide effect of alphacypermethrin was assessed on adobe surface with plaster, adobe without plaster, and wood. There was $100.0 \%$ mortality with all three surfaces, which confirms that the surface does not play a major role in sensitivity.

Considering that the study populations were highly susceptible to alpha-cypermethrin, an insecticide currently used by the Brazilian Ministry of Health for triatomine control in the field, the difficulties in controlling these populations can be related to the abundance and complexity of peridomiciles of the region studied. The peridomicile presents a wide variety of ecotopes corresponding to an infinite number of hidden loci associated with different sources of food for T. sordida, such as chickens, dogs, pigs, and cats. Spraying the peridomicile is exhausting work in which unshackling all of the material accrued is operationally impossible for the field agent in charge. After insecticide application, eggs and triatomines (nymphs and adults) may either be completely free of contact with active chemicals, or could be in contact with sub-lethal doses, thus selecting for the specimens less susceptible to the chemicals and allowing for the survival of those insects in such ecotopes ${ }^{(17)(18)}$. This underscores the finding that different pyrethroids exhibit ovicidal action when the insecticide is applied directly to the exochorial components of eggs ${ }^{(19)}$. Furthermore, operational failures may contribute to the control difficulties, revealing the urgent need for technical improvement of the field team in charge. The control failures may be caused by lack of efficacy of the insecticide, by operational failures and/or environmental conditions. The lack of insecticide efficacy is related to poor quality of the active ingredient and/or inadequate formulation. Operational failures cover the insecticide dilution errors, failures in applications as well problems with spraying machines ${ }^{(5)}$. One should also consider the discontinuity of spraying cycles for administrative, budgetary, and logistical reasons ${ }^{(17)(18)(20)}$. Finally, the presence of wild foci of T. sordida in the region should be considered, as it is associated with significant mobility of this triatomine (mostly adults), which facilitates the process of dispersal and colonization of artificial ecotypes ${ }^{(20)}$, thereby hindering control.

Although in this study, the resistant populations in laboratory tests were actually susceptible in the field, this observation in itself is insufficient to justify changing the cut-off points used for setting the $\mathrm{RR}_{50}$, how as conducted by the Ministry of Health of Brazil by the integrated management of the insecticide resistance of Aedes aegypti ${ }^{(9)}$. Indeed, we recommend that laboratory and field bioassays are carried out with a greater number of Triatominae populations to allow more thorough evaluation of the critical parameters. We recommend that these studies should be carried out on the timeline, once the triatominic populations is being pressed continuously by insecticides used by National Program of Chagas Disease Control in Brazil. This is particularly important in areas with overlap of endemics and/or agricultural areas, as these locations may intensify and even accelerate the selection of resistant genes that may exist in these populations.

\section{ACKNOWLEDGMENTS}

We would like to thank the Secretaria de Saúde do Estado de Minas Gerais (SES/MG) for the collection of Triatominae and the Instituto Nacional de Metereologia (INMET) for the meteorological data.

\section{CONFLICT OF INTEREST}

The authors declare that there is no conflict of interest. 


\section{FINANCIAL SUPPORT}

This study was supported by the Conselho Nacional de Desenvolvimento Científico e Tecnológico (CNPq), the Fundação de Amparo a Pesquisa do Estado de Minas Gerais (FAPEMIG), the Centro de Pesquisas René Rachou (CPqRR), the Fundação Oswaldo Cruz (FIOCRUZ), the Secretaria de Vigilância em Saúde (SVS), the Ministério da Saúde (MS), Brazil, and the World Health Organization (WHO).

\section{REFERENCES}

1. Brow AQ, Paul R. Insecticide resistance in arthopods. WHO Monogr Geneva Ser 38. Geneva: World Health Organization; 1971.

2. Tabashink BE, Roush RT. Introduction. In: Roush RT, Tabashink $\mathrm{BE}$, editors. Pesticide resistance in arthropods. New York: Chapman and Hall; 1990. p. 1-3.

3. Pessoa GCD. Perfil da suscetibilidade a deltametrina em populações de Triatoma sordida (Hemiptera: Reduviidae) do Estado de Minas Gerais procedentes de áreas com infestação persistente. 2012. 179p. (Doctor's Thesis). Universidade Federal de Minas Gerais; 2012 Belo Horizonte.

4. Zerba EN, Picollo MI. Resistencia a insecticidas piretroides en Triatoma infestans. Centro de Investigaciones de Plagas e Insecticidas (CIPEIN). Buenos Aires, Argentina: CITEFACONICET; 2002.

5. Pan American Health Organization (PAHO). II Reunion técnica latinoamericana de monitoreo de resistência a insecticidas em triatominos vectores de Chagas. Panamá: PAHO; 2005.

6. Pessoa GCD, Dias LS, Diotaiuti L. Deltamethrin pyrethroid susceptibility characterization of Triatoma sordida Stal, 1859 (Hemiptera: Reduviidae) populations in the Northern Region of Minas Gerais, Brazil. Rev Soc Bras Med Trop 2014; 47:426-429.

7. Pessoa GCD, Pinheiro LC, Ferraz ML, Mello BV, Diotaiuti L. Standartization of laboratory bioassays for the study of Triatoma sordida susceptibility to pyrethroid insecticides. Parasit Vectors 2015; 8:109-114.

8. Lent H, Wygodzinsky P. Revision of the Triatominae (Hemiptera, Reduviidae), and their significance as vectors of Chagas'disease. Bull Amer Mus Nat Hist 1979;163.
9. Ministério da Saúde. II Seminário internacional sobre técnicas e ferramentas de controle de doenças transmitidas por vetores recomendações. Brasília: Superintendência de Vigilância em Saúde; 2006.

10. World Health Organization (WHO). Taller sobre la evaluación de efecto insecticida sobre triatominos. Workshop on the insecticide effect evaluation in triatominos. Acta Toxicol Argentina 1994; 2:29-33.

11. Obara TM. Caracterização da resistência a inseticidas em populações da subfamília Triatominae (Hemiptera: Reduviidae), vetores de Trypanosoma cruzi Chagas, 1909. 2010. 246p. (Doctoral Thesis). Universidade de São Paulo, 2010. São Paulo.

12. Dias JCP. Observações sobre o comportamento de triatomíneos brasileiros frente ao jejum em laboratório. Rev Bras Malar $1965 ; 17: 55-63$.

13. Santo-Orihuela PL, Vassena CV, Zerba EM, Picollo MI. Reltive contribution of monooxygenase and esterase to pyrethroid resistance in Triatoma infestans (Hemiptera: Reduviidae) from Argentina and Bolivia. J Med Entomol 2008; 45:298-306.

14. Oliveira Filho AM, Melo MTV. Field trial of the pyrethroid bifenthrin (OMS 3024) against triatomines in an area of $T$. infestans colonization - Riachão das Neves, BA. Cienc Cult 1987; 39:817.

15. Marcondes CB, Pinto CT. Avaliação da deltametrina (K-Othrine 50 FW), em doses baixas, no controle de triatomíneos em São Paulo do Umbuzeiro, Paraíba. Rev Soc Bras Med Trop 1989; 22:85-90.

16. Diotaiuti L, Pinto CT. Suscetibilidade biológica do Triatoma sordida e Triatoma infestans a deltametrina e lambdacyalotrina em condições de campo. Rev Soc Bras Med Trop 1991; 24:151-155.

17. Porcasi X, Catala SS, Hellac H, Scavuzzo MC, Gorla DE. Infestation of rural houses by Triatoma infestans (Hemiptera: Reduviidae) in Southern área of Gran Chaco in Argentina. J Med Entomol 2006, 43:1060-1067.

18. Gurtler RE, Canale DM, Spillmann C, Striolo R, Salomón OD, Blanco S, et al. Effectiveness of residual spraying of peridomestic ecotopes with deltamethrin and permethrin on Triatoma infestans in rural western Argentina: a district wide randomized trial. Bull World Health Organ 2004; 82:196-205.

19. Rodrigues VLC, Ferraz Filho NA, Rocha e Silva EO, Ishihata GK. Triatomíneos: ação ovicida de alguns piretróides. Rev Soc Bras Med Trop 2002; 35:237-241.

20. Forattini OP, Rocha e Silva EO, Ferreira AO, Rabello EX, Patolli DGB. Aspectos ecológicos da tripanossomíase Americana. III. Dispersão local de triatomíneos, com especial referência ao Triatoma sordida. Rev Saude Publica 1971; 5:193-205. 